\title{
The importance of differentiating types of myxoma: a case report
}

\author{
Tri W. Soetisna ${ }^{a, b}$, Lisca Namrettaa, Edward S. Tirta ${ }^{a}$, M. Marliando S. P. Catura, \\ Bagus Ronidipta ${ }^{a}$, Amin Tjubandi ${ }^{a, b}$
}

a Department of Cardiothoracic and Vascular Surgery, National Cardiovascular Centre Harapan Kita, Jakarta, Indonesia

${ }^{b}$ Department of Surgery, Faculty of Medicine, Universitas Indonesia, Indonesia

\section{ARTICLE INFO}

Article history:

Submitted: 19. 4. 2021

Accepted: 23. 5. 2021

Available online: 1. 12. 2021

Klíčová slova:

Klky na povrchu

Myxom

Nádor

\section{SOUHRN}

Myxom je spojen s nespecifickými symptomy podobnými jiným srdečním onemocněním. Pozdní resekce myxomu zhoršuje další vývoj onemocnění, například rozvoj městnavého srdečního selhání, vznik arytmií, srdeční embolie, případně náhlé srdeční smrti. Diagnózu je nutno stanovit a chirurgickou excizi srdečních myxomů, zvláśtě těch $s$ klky na povrchu, provést co nejdřive. Aby se zabránilo komplikacím, bylo nutno provést další diagnostické vyšetření umožňující definovat typy myxomů pro časné zahájení léčby. Popisujeme prípad síňového myxomu, který byl diagnostikován a odstraněn dříve, než byl medián doby uváděné ve starší studii. Tento článek upozorňuje na význam časného stanovení diagnózy a definování typů myxomů.

(c) 2021, С̌KS.
Keywords:

Myxoma

Tumor

Villous surface

\begin{abstract}
Myxoma shows unspecific symptoms similar to other cardiac disorders. Late resection of myxoma will worsen output such as congestive heart failure, cardiac arrhythmia, and cardiac embolism, causing sudden death. Early diagnosis and surgical excision of cardiac myxomas, especially with the villous surface, must be done as soon as possible. Additional diagnostic examination was needed to define types of myxoma for earlier treatment to prevent complications. We present a case of atrial myxoma which was diagnosed and treated earlier than the median time reviewed by the previous study. This paper focuses on the importance of early diagnosis and defining types of myxoma.
\end{abstract}

\section{Introduction}

Left atrial myxomas usually show unspecific symptoms and similar to the other cardiac disorders. The symptoms may rapidly become severe and associated with heart failure. Laboratory findings are usually normal. ${ }^{1}$ Electrocardiographic results associated with myxomas are not specific but may include arrhythmias and conduction disturbances. Atrial fibrillation, bundle branch block, and abnormal $P$ waves occur typically. ${ }^{2}$ Generalized cardiomegaly or typical chamber enlargement may be seen in the chest radiograph, particularly in the case of large myxomas that caused an obstruction. Transthoracic echocardiography (TTE) supplemented by transesophageal echocardiography (TEE) has become the most appropriate screening and diagnostic imaging modality for myxomas. ${ }^{2,3}$

\section{Case report}

A 49-year-old Asian male was presented to the Emergency Department of National Cardiovascular Centre with shortness of breath within five days. The patient had no previous family history of tumours. The vital signs were good and stable. The patient's physical examination revealed that both lungs had bronchi with no wheezing and cardiovascular study revealed holosystolic murmur sound grade 3/6 at the apex. The abdomen was soft, non-tender, non-distended with normal bowel sounds in all four quadrants. The pulses were intact bilaterally in the upper and lower extremities with no edema.

The laboratory findings were as follows: WBC $8700 \mathrm{~K} /$ $\mu \mathrm{L}, \mathrm{Hb} 12.1 \mathrm{~g} / \mathrm{dL}$, Hct $35.7 \%$, platelets $369.000 \mathrm{~K} / \mu \mathrm{L}$. Electrolyte panel findings were as follows: $\mathrm{Na} 130 \mathrm{mmol} / \mathrm{L}$, 


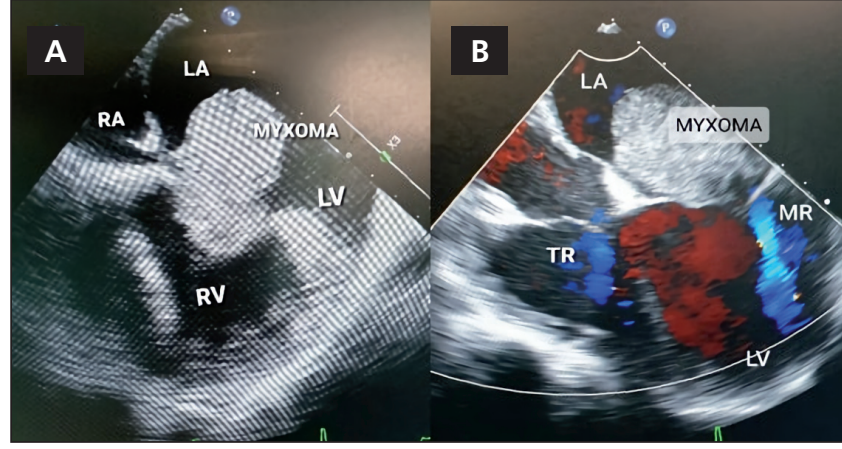

Fig. 1 - Transthoracic echocardiography in mid-oesophageal four-chamber view. (A) A large LA myxoma filling almost the whole LA and affecting the mitral valve. (B) A color Doppler is added.

$\mathrm{K} 4.4 \mathrm{mmol} / \mathrm{L}$, chloride $89 \mathrm{mmol} / \mathrm{L}, \mathrm{Cr} 0.8 \mathrm{mg} / \mathrm{dl}$, glucose: $86 \mathrm{mg} / \mathrm{dl}$. ECG showed sinus bradycardia. On TTE examination a large mass in the left atrium $(3 \mathrm{~cm} \times 7.5 \mathrm{~cm})$ was found with $48 \%$ ejection fraction and moderate mitral regurgitation (Fig. 1).

This patient was diagnosed with left atrial myxoma with moderate mitral valve regurgitation and was decided to undergo an urgent surgery five days after diagnosis. A median sternotomy was performed. After the cardiopulmonary bypass machine (CPB) was run, a total bypass was carried out. Then an aortic cross-clamp was performed followed by antegrade cardioplegic administration. The right atrial transseptal approach was chosen because we assume the myxoma stalk was at the septum; hence the right atrium was opened, we continued with the incision for opening the interatrial septum. The position of the myxoma stalk was identified.

The base of myxoma stalk located in the cranial portion of the fossa ovalis $2.5 \mathrm{~cm} \times 2.5 \mathrm{~cm}$ at the interatrial septum and extends into the cranial wall of the left atrium 3 $\mathrm{cm} \times 2 \mathrm{~cm}$. Myxoma that fills the left atrium and reaches the mitral valve leaflet could be removed completely. Removal of the base of the myxoma causes a defect on the left atrium roof in with a height of $4 \mathrm{~cm}$ and a base of 2 $\mathrm{cm}$. Myxoma measures were $7.5 \mathrm{~cm} \times 2.5 \mathrm{~cm} \times 2 \mathrm{~cm}$; the colour was greenish, gelatinous in consistency, mobile, with fine borders and villous surface; Fig. 2.

The mitral valve identification was then performed. It was found that there was anterior valve leaflet prolapse between P2 and P3 due to cord elongation and

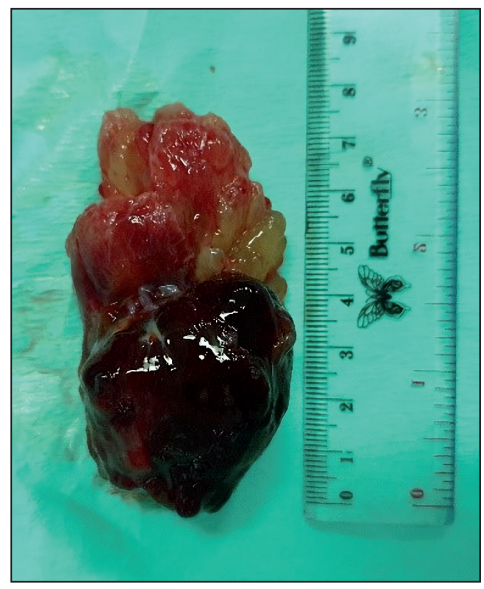

Fig. 2 - A left atrial myxoma with a size of $7.5 \mathrm{~cm} \times 2.5 \mathrm{~cm} \times 2 \mathrm{~cm}$

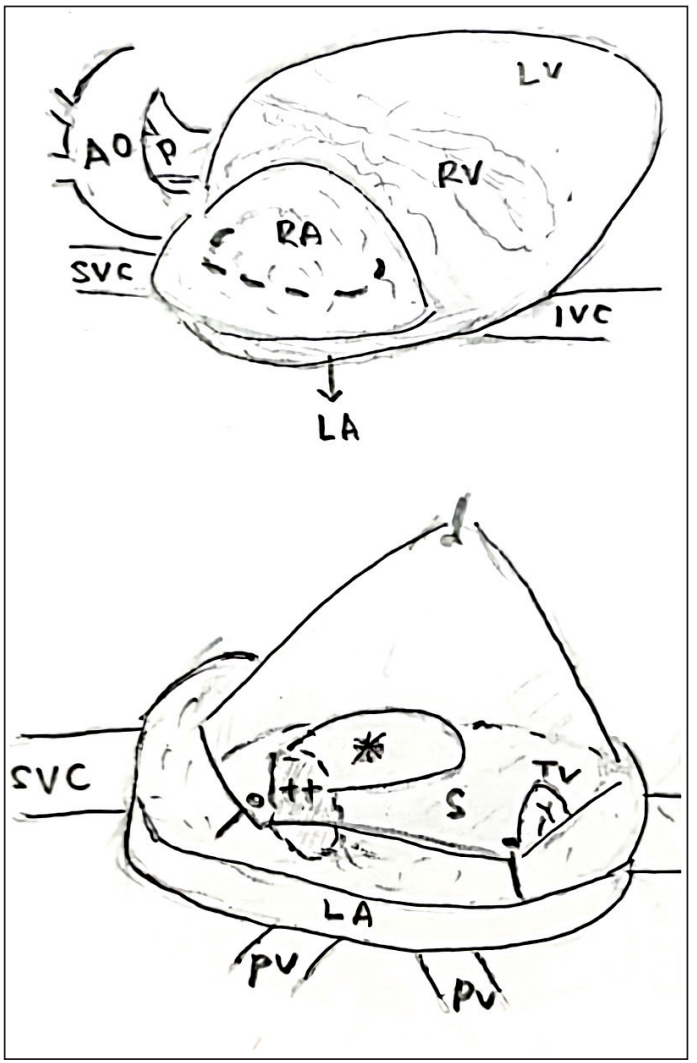

Fig. 3 - Intraoperative ilustration. (A) Before incision of RA. (B) After incision of RA. - incision line; AO - aorta; IVC - inferior vena cava; LA - left atrium; LV - left ventricle; P - pulmonary artery; RA right atrium; RV - right ventricle; SVC - superior vena cava.

mitral valve annulus dilatation. Foldingplasty was done between P2 and P3 followed by ring annuloplasty using mitral ring C-E Physio number $28 \mathrm{~mm}$ (Edwards Lifesciences) with a total of 16 stitches. The defect in the cranial left atrial that extends to the intersection of the left and right septal atrial wall with interatrial septum was closed by direct suturing. The interatrial septum defect was closed using a pericardial patch. Illustrations on surgical approach were described in Figure 3. Cardiopulmonary bypass was quickly discontinued without any problem. Then the surgery was done smoothly. Postoperative TEE showed no recurrence of the tumour, and the mitral valve that has been attached to the annular ring is functioning correctly.

Pathology examination shows the tumour type was myxoma tumour, and there is also a tumour tissue composed of oval nucleated stellate cells/spindles between the broad myxoid stroma. Hypocellular and hypercellular areas were seen; there's also foci of prolonged bleeding with hemosiderophage pigments, lymphocytes, and macrophages. Complete resection was achieved, and the patient has no symptoms of recurrence in six-month follow-up.

\section{Discussion}

As we know, shortness of breath has a very broad differential diagnosis, which can be caused by various cardiac aetiologies; ischemic heart disease, hypertensive 
heart failure, cardiomyopathy, etc. Therefore, supporting examinations are needed in addition to a good history and physical examination. ${ }^{4,5}$ Our patient came to the emergency room complaining of shortness of breath. We found a mass suspected as myxoma in the left atrium on echocardiography in this patient. Mitral regurgitation also found and was probably due to a mass (myxoma) pressing on the annulus that causes dilation.

Cardiac myxoma is the most common form of tumour in heart and usually comes in many different symptoms. Most common symptoms mainly were dyspnoea, followed by constitutional symptoms, and embolic symptoms. A study by Cianciulli et al. stated that the median time since symptom onset until diagnosis was 14 weeks with median time from echocardiographic diagnosis to surgery being 12 days. A late resection of myxoma will worsen output such as congestive heart failure, cardiac arrhythmia, and cardiac embolism, causing sudden death. Surgical excision of cardiac myxomas, especially with villous surface, must be done as soon as possible after the diagnosis is established because of the high risk of valvular obstruction or systemic embolization. ${ }^{5}$ In our case, the patient was diagnosed with myxoma five days from symptom onset and underwent surgery five days after echocardiographic diagnosis. The early diagnosis was due our hospital's protocol to do TTE examination in patient with cardiac dyspnoea. Therefore, emergency department should be ready to do echocardiography and aware of myxoma triad, which includes embolic, obstructive phenomena, and constitutional symptoms.

Embolic symptoms, which could cause emergent condition, commonly occur in myxoma with villous surface. Myxoma's type could only be distinguished by either 3D transoesophageal echocardiography (3D TEE) or computed tomography (CT) scan. Although there is no study regarding specificity and sensitivity of both modalities in detecting types of myxoma. ${ }^{6,7}$ In our case, the patient underwent 2D echocardiography, which is a standard modality in diagnosing myxoma, but didn't underwent 3D TEE nor CT scan to differentiate the types of myxoma. This was due to economic causes and lack of awareness in the importance of differentiating types of myxoma. Nevertheless, we still recommend additional diagnostic examination to define types of myxoma for earlier treatment to prevent complication.

Myxoma requires early diagnosis and treatment to prevent sudden death, embolization, and systemic symp- toms. Surgical approach could minimize recurrence of the tumour, and was stated to be safe and efficacious. The surgical approach for atrial myxomas should provide adequate exposure of the tumour that allow minimal manipulation for complete resection to achieve safe and efficacious procedure. ${ }^{4}$

\section{Conclusion}

Early diagnosis of myxoma, especially the villous type, should be made to prevent complication such as embolic event that could worsen output. Study to find specific modalities in differentiating myxoma type could be made for better outcome in myxoma cases.

\section{Ethical statement}

The authors declare that no experiments were performed on humans of animals for this investigation.

\section{Confidentiality of data}

The authors declare that no patient data appear in this article.

\section{Right to privacy and informed consent}

The authors declare that no patient data appear in this article.

\section{References}

1. Davioli D, Muzzi L, Lucchese G, et al. Large Left Atrial Myxoma with Severe Mitral Regurgitation. Tex Heart Inst J 2006;33:5153.

2. Kouchoukos N, Blackstone E, Hanley F, Kirklin J. Cardiac Surgery. 4th Edition. Philadelphia: Elsevier Inc. 2013:751-757.

3. Fisher J. Cardiac myxoma. Cardiovasc Rev Reports 1983;4:11951199.

4. Garatti A, Nano G, Canziani A, et al. Surgical Excision of Cardiac Myxomas: Twenty Years Experience at a Single Institution. Ann Thorac Surg 2012;93:825-831.

5. Cianciulli T, Cozzarin A, Soumoulou J, et al. Twenty Years of Clinical Experience with Cardiac Myxomas: Diagnosis, Treatment, and Follow Up. J Cardiovasc Imaging 2019;27:3747.

6. Scheffel $H$, Baumueller S, Stolzmann $P$, et al. Atrial Myxomas and Thrombi: Comparison of Imaging Features on CT. AJR Am J Roentgenol 2009;192:639-645.

7. Aydın C, Taşal A, Ay Y, et al. A giant right atrial villous myxoma with simultaneous pulmonary embolism. Int J Surg Case Rep 2014;5:206-208. 